\title{
Acid Ceramidase
}

National Cancer Institute

\section{Source}

National Cancer Institute. Acid Ceramidase. NCI Thesaurus. Code C103901.

Acid ceramidase (395 aa, $\sim 45 \mathrm{kDa}$ ) is encoded by the human ASAH1 gene. This protein plays a role in sphingosine biosynthesis. 